\title{
The Impact of Political Stability and Firm-Specific Variables on the Performance of Islamic Banks in Pakistan
}

\author{
${ }^{1}$ Ali Burhan Khan, ${ }^{2}$ Ammara Sarwar, ${ }^{3}$ Dr. Dinesh Kumar Saundra Rajan, ${ }^{4}$ Dr. Muhammad Nawaz \\ ${ }^{1} \mathrm{PhD}$. Scholar, School of Economics, Finance and Banking University Utara Malaysia, Malaysia. aliburhan963@ gmail.com \\ ${ }^{2} \mathrm{PhD}$. Scholar, Lahore School of Accountancy and Finance, The University of Lahore, Pakistan. ammara.sarwar@sgd.uol.edu.pk \\ ${ }^{3}$ Assistant Professor, Faculty of Business and Finance, University Tunku Abdul Rahman, Malaysia. dineshk@utar.edu.my \\ ${ }^{4}$ Assistant Professor, School of Commerce and Accountancy, Minhaj University Lahore, Pakistan. drnawaz.sca@mul.edu.pk
}

\begin{abstract}
Financial sector of a country plays pivotal role in the economic advancement. Therefore, the aim of this study is to analyze the performance determinants of 5 Islamic banks in Pakistan which remain active from year 2006 to 2018. By applying the Random Effect Model (REM), this study concluded that leverage and size of Islamic banks contributed significantly towards their performance. However, Islamic banks' performance remained unaffected with respect to change in political stability level and liquidity. Therefore, this study has implication for Islamic banks managers that instead of considering political environment of Pakistan, focus should be made on bank specific matters.
\end{abstract}

Keywords: Banks, Political Stability, Performance, Pakistan

Article Received: 18 October 2020, Revised: 3 November 2020, Accepted: 24 December 2020

\section{Background and Motivation of Study}

As the global economy is growing with rapid pace along with the economic expansion of Islamic countries, the Islamic banking is also emerging as a major player in the global economy (Butt el al. 2011). According to Islamic Finance Development Report (2018) the Islamic finance industry is growing at the pace of $11 \%$ since year 2012 and its size has reached to US\$2.4 trillion. Out of this, the share of Islamic banks is $71 \%$ or US\$ 1.7 trillion. Furthermore, such emergence of Islamic banking is not just confined to Muslim countries, but nonMuslim countries are also part of this (Irfan, Majeed \& Zaman, 2014). For instance, as of year 2017, total 505 Islamic banks are operating globally.

Islamic baking is defined by State Bank of Pakistan (2020) as "A system which is in consonance with the spirit, ethos and value system of Islam and governed by the principles laid down by Islamic Shariah". Islamic banking philosophy emerged from Islamic Shariah laws. Under such laws, Islamic banks cannot involve in the transections related to riba or interest, Gharar or Maiser, and such transactions which are considered haram under Islamic principles. Therefore, Islamic banks can generate income from such investment tool which fulfill Sharia compliance criteria.

Islamic finance history in Pakistan goes back to 1970s when wide scale efforts started to eliminate the concept of riba (interest) (Khan, Khan, \& Tahir, 2017). However, the efforts did not transform into practical form until the State Bank of Pakistan, on December 23, 1999, approved the different types of Islamic financing modes such as Mudaraba, Musharaka, Musawama, Murabaha, Leasing, Istisna and Salam (State Bank of Pakistan, 2020). Currently, in context of the Islamic banking industry of Pakistan, it is also growing at the remarkable pace of 7.3 percent with total assets worth of PKR. 2,992 billion. In addition, currently it is holding $14.4 \%$ market share in the banking industry of Pakistan (State Bank of Pakistan, 2019). Overall, the Islamic banking system's history in Pakistan is not much longer as compared to the history of conventional banks (Khan el al., 2020).

To keep continue the current pace, it is imperative for Islamic banks managers to be familiar with the factors which create impact on the Islamic banks' performance. Therefore, this current study aims at analyzing the impact of political stability and firm- 
specific variables (leverage, liquidity and size) on the Islamic banks' performance in Pakistan. As it was stated by Mark and Nwaiwu (2015) that political actions in a country can negatively influence the profitability of businesses and may act as a barrier towards foreign investment. In context of Islamic banks in Pakistan, the impact of political stability on their performance is not investigated before.

\section{Literature Review}

Although, Islamic banking system has a shorter history as compared to the conventional banks, it is attaining an increasing attention of policy makers, investors and researchers (Rashid, Yousaf \& Khaleequzzaman, 2017). In terms of leverage, it reflects a company's ability to write new business without putting financial strain on its existing capital base (Adams, Burton, \& Hardwick, 2003). If a company use more debt, it can get benefit in form of less income tax. The use of debt to a certain level can increase the profitability (Omondi \& Muturi, 2013). Accordingly, previous studies (Akhtar, Ali \& Sadaqat, 2011, Khan, Ijaz \& Aslam, 2014; Masood \& Ashraf, 2012) also concluded positive association among leverage and Islamic banks profitability. However, it was argued by Omondi and Muturi (2013), as leverage increases, financial risk also increases. As a result, downfall in the profitability of Islamic banks may occur. As a study done by Obeidat, El-Rimawi, Maqableh and Al-Jarrah (2013) in the market of Jordan also found negative impact of leverage on Islamic banks' performance. Therefore, this study also hypothesizes the existence of negative relation between leverage and the profitability of Islamic banks in Pakistan.

Liquidity is also an important factor for the existence and development of a company (Sanghani, 2014). It is very difficult to select the best performing company since it might have a high level of profitability but stuck in very bad liquidity issues (Omondi and Muturi, 2013). According to Hasan and Soula (2017), the banks which produce more liquidity may not be liquidity efficient. Furthermore, Al-Qudah and Jaradat
(2013) as well as Sanwari and Zakaria (2013) also reported the significant negative linkage among the liquidity and Islamic banks' performance in the market of Jordan and selected Islamic countries respectively. Thus, this study also claims the negative relationship between liquidity and Islamic banks performance in Pakistan.

According to Almajali, Alamro and Al-Soub (2012) size of a firm is an important factor in defining of its market power. Therefore, larger market power makes it difficult for small firms to compete with larger one. In addition, large size firms can also achieve economies of scale and scope which make them more efficient. Moreover, they have larger capacity to tackle the adverse market conditions and can easily recruit the employees which have better professional knowledge (Zainudin, Mahdzan \& Leong, 2018). In the same way, the supporter of trade-off theory claims that the larger the firm size, the more diversified it would be. Therefore, its chances of bankruptcy reduce (Sheikh \& Qureshi, 2017). In addition, Al-Qudah and Jaradat (2013) and Masood and Ashraf (2012) also concluded the significant positive influence of firm size on the Islamic banks' performance in the market of Jordan and Pakistan respectively. Thus, this study asserts a positive association of size with the Pakistani Islamic banks.

According to Shahzad and Al-Swidi (2013) political stability contributes significantly towards business environment of a country. Furthermore, study done by Anwar, Abbass and Shaikh (2019) concluded that political stability has significant positive relationship with firm performance. However, their study did not specifically target the Islamic banking sector. Accordingly, Sanlisoy, Aydin and Yalcinkaya (2017) claimed that political stability is one of the potential factors which can impact the banks' profitability. Thus, this study expects the positive influence of political stability on Islamic banks performance.

\section{Gaps in Existing Literature}

Although there is considerable research done regarding Islamic banks performance (Rashid, 
Yousaf \& Khaleequzzaman, 2017), still there is lack of research on political stability in the context of the Islamic banks' performance. As it was also stated by Anwar et al. (2019), there is limited number of studies which address the association between political stability and the performance of firm. As it was indicated by Khan, Basheer, Iqbal and Hatim (2020), managers of Sharia compliance companies should have the knowledge of overall macro-economic environment. Therefore, this study contributes in existing literature by introducing political stability along with other firm-specific variables (leverage, liquidity and size) with respect to the Islamic banks' profitability in Pakistan.

\section{Data and Methodology}

In this study, the data of 5 Islamic banks, which remained active from year 2006 to 2018, was collected. The balance panel of the data was made which was based on 65 observations.

Table 1: Measurement of Political Stability and Selected Firm-Specific Variable

\begin{tabular}{llll}
\hline Variable & Notation & Measurement & Data Source \\
\hline Profitability & PRO & Earnings Per Share (Net profit after tax/Total ordinary shares) & $\begin{array}{l}\text { State Bank of } \\
\text { Pakistan } \\
\text { Leverage }\end{array}$ \\
LEV & Total deposit divided by total equity & $\begin{array}{l}\text { State Bank of } \\
\text { Pakistan } \\
\text { Liquidity }\end{array}$ \\
LIQ & Cash and bank balances/total assets & Total assets & $\begin{array}{l}\text { State Bank of } \\
\text { Pakistan } \\
\text { Size }\end{array}$ \\
Political Stability & PS & $\begin{array}{l}\text { Probability of political instability or politically motivated } \\
\text { violence and terrorism. }\end{array}$ & $\begin{array}{l}\text { Pakistan } \\
\text { World Bank }\end{array}$ \\
\hline
\end{tabular}

Source: Author's Own Compilation Based on Previous Literature

Table 1 provides an overview of calculation procedure and data sources of selected variables. In addition, the mathematical equation of the analysis is formed as below:

$$
\begin{gathered}
\mathrm{PRO}_{\mathrm{it}}=\beta_{1}+\beta_{2} \mathrm{LEV}_{\mathrm{it}}+\beta_{3} \mathrm{LIQ}_{\mathrm{it}}+\beta_{4} \mathrm{SIZ}_{\mathrm{it}}+\beta_{5} \mathrm{PS}_{\mathrm{it}} \\
+\mu_{\mathrm{t}}
\end{gathered}
$$

Whereas:

$\mathrm{PRO}_{\text {it }}=$ Profitability of Islamic Banks $i$ at time $t$; $\mathrm{LEV}_{\text {it }}=$ Leverage $i$ at time $t ; \mathrm{LIQ}_{\mathrm{it}}=$ Liquidity $i$ at time $t ; \mathrm{SIZ}_{\mathrm{it}}=$ Size $i$ at time $t ; \mathrm{PS}_{\mathrm{it}}=$ Political Stability $i$ at time $t ; \beta_{1}=$ Intercept; $\mu_{\mathrm{t}}=$ error term

\section{Results and Interpretations}

In this study Hausman test was conducted to make selection among Fixed Effect Model (FEM) and Random Effect Model (REM). The result of Hausman test found to be insignificant which highlight that REM is most appropriate model for this study. In addition, different diagnostic tests such as normality, autocorrelation, heteroscedasticity and multicollinearity were also applied to fulfill the REM assumptions. The results of all these tests are reported in appendix.

Table 2: Fixed Effect Model Results

\begin{tabular}{llll}
\hline Variable & Beta Coefficient & T-stat & P-value \\
\hline C & -21.622 & -7.354 & 0 \\
LEV & $-0.092^{* * *}$ & -2.882 & 0.005 \\
LIQ & 2.067 & 1.094 & 0.278 \\
SIZ & $1.275^{* * *}$ & 7.704 & 0 \\
PS & 0.133 & 1.190 & 0.238 \\
\hline
\end{tabular}

$\begin{array}{ll}\text { R-squared }\left(\mathbf{R}^{\mathbf{2}}\right) & 0.518 \\ \text { Adjusted } \mathbf{R}^{\mathbf{2}} & 0.486\end{array}$


* P-value $\leq 0.1>0.05$

$* * \mathrm{P}$-value $\leq 0.05>0.01$

$* * * \mathrm{P}$-value $\leq 0.01$

In the table 2, the results related to political stability and firm specific determinants of Islamic banks performance in Pakistan are reported. With respect to the results, LEV and SIZ has highly significant association with the performance of Islamic banks. Whereas, LIQ and PS have insignificant relationship. In terms of linkage among leverage and Islamic banks' performance, increases in leverage results in lower performance of the Islamic banks. It is because of increase in financial risk (Omondi \& Muturi, 2013) which emerges as a result of increase in leverage. Thus, this phenomenon reduces the Islamic banks' profitability in Pakistan. This result is also supported by the Obeidat et al. (2013) who empirically proves the negative impact of leverage on the performance of Jordanian Islamic banks.

This study found the positive association among Islamic banks' size and profitability. It means Islamic banks can enjoy higher profit by increasing their size. It is since increase in firm size enable it to achieve economy of scale and scope. Additionally, it also increases the firm market power (Almajali et al. 2012) and reduces its chances of bankruptcy (Sheikh \& Qureshi, 2017) which increases the profits of Islamic banks operating in Pakistan. This result is also in line with Al-Qudah and Jaradat (2013) and Masood and Ashraf (2012) studies which established a positive association among size and Islamic banks' profitability in Jordanian and Pakistani market.

\section{Conclusion}

Islamic banking is an alternative financial system based on Islamic or Shariah laws. So, to analyze the performance of such alternative financial system, the empirical framework of this study enabled the researcher to identify the role of political stability, along with firm specific variables (leverage, liquidity and size) regarding explaining Islamic banks performance. This study found that the level of political stability in Pakistan does not play any role in defining the Islamic banks' performance. Nonetheless, Islamic banks can enjoy higher performance by increasing their size. However, increase in leverage can impair their performance. At the end, this study is not only useful for the bank managers, but at the same time it also educates the bank customers, investors and policy makers with respect to Islamic banks performance.

\section{REFERENCES}

[1] Adams, M., Burton, B., \& Hardwick, P. (2003). The determinants of credit ratings in the United Kingdom insurance industry. Journal of Business Finance \& Accounting, 30(3-4), 539-572. https://doi.org/10.1111/1468-5957.00007

[2] Akhtar, M. F., Ali, K., \& Sadaqat, S. (2011). Factors influencing the profitability of Islamic banks of Pakistan. International Research Journal of Finance and Economics, 66(66), 1-8.

[3] Almajali, A. Y., Alamro, S. A., \& Al-Soub, Y. Z. (2012). Factors affecting the financial performance of Jordanian insurance companies listed at Amman Stock Exchange. Journal of Management Research, 4(2), 266-289. http://dx.doi.org/10.5296/jmr.v4i2.1482

[4] Al-Qudah, A. M., \& Jaradat, M. A. (2013). The impact of macroeconomic variables and banks characteristics on Jordanian Islamic banks profitability: Empirical evidence. International Business Research, 6(10), 153-162. http://dx.doi.org/10.5539/ibr.v6n10p153

[5] Anwar, Z., Abbass, K., \& Shaikh, S. (2019). Impact of political stability and managerial ownership on firm's 
profitability. Journal of Business Strategies, 13(1).

[6] Butt, I., Saleem, N., Ahmed, H., Altaf, M., Jaffer, K., \& Mahmood, J. (2011). Barriers to adoption of Islamic banking in Pakistan. Journal of Islamic Marketing, 2(3), 259-273. https://doi.org/10.1108/175908311111647 87

[7] Hasan, I., \& Soula, J. L. (2017). Technical Efficiency in Bank Liquidity Creation (Working Paper). University of Strasbourg. Retrieved from http://ifs.ustrasbg.fr/large/publications/2017/201708.pdf

[8] Irfan, M., Majeed, Y., \& Zaman, K. (2014). The performance and efficiency of Islamic banking in South Asian countries. Economia Seria Management, 17(2), 223-237.

[9] Islamic Finance Development Report. (2018). Building Momentum. Retrieved from https://ceif.iba.edu.pk/pdf/ReutersIslamic-finance-developmentreport2018.pdf

[10] Khan, M. M. S., Ijaz, F., \& Aslam, E. (2014). Determinants of profitability of Islamic banking industry: An evidence from Pakistan. Business \& Economic Review, 6(2), 27-46.

[11] Khan, I., Khan, M., \& Tahir, M. (2017). Performance comparison of Islamic and conventional banks: empirical evidence from Pakistan. International Journal of Islamic and Middle Eastern Finance and Management, 10(3), 419-433. https://doi.org/10.1108/IMEFM-05-20160077

[12] Khan, A. B., Noreen, M., Hassan E. U., Sarwar, A., Aktar, M. A., Hatim, M., \& Abbas, F. (2020). Does the age of Islamic Banks matter? A case study of Pakistan. International Journal of Innovation, Creativity and Change. 13(11), 13-24.

[13] Khan A. B., Basheer, M. F., Iqbal J., \& Hatim, M. (2020). Global Financial Crisis
2008-09, macro-economic variables and the performance of FTSE Bursa Malaysia Hijrah Shariah Index: A case of Malaysian Stock Market. Hamdard Islamicus. 43(1). 94-99.

[14] Mark, J., \& Nwaiwu, J. N. (2015). Impact of political environment on business performance of multinational companies in Nigeria. African Research Review, 9(3), 110. https://doi.org/10.4314/afrrev.v9i3.1

[15] Masood, O., \& Ashraf, M. (2012). Bankspecific and macroeconomic profitability determinants of Islamic banks. Qualitative Research in Financial Markets, 4(2), 255268.

https://doi.org/10.1108/175541712112525 65

[16] Obeidat, B., El-Rimawi, S., Maqableh, M., \& Al-Jarrah, I. (2013). Evaluating the profitability of the Islamic banks in Jordan. European Journal of Economics, Finance and Administrative Sciences, 56, 27-36.

http://www.eurojournals.com/EJEFAS.htm

[17] Omondi, M. M., \& Muturi, W. (2013). Factors affecting the financial performance of listed companies at the Nairobi Securities Exchange in Kenya. Research Journal of Finance and Accounting, 4(15), 99-104.

[18] Rashid, A., Yousaf, S., \& Khaleequzzaman, M. (2017). Does Islamic banking really strengthen financial stability? Empirical evidence from Pakistan. International Journal of Islamic and Middle Eastern Finance and Management, 10(2), 130-148. https://doi.org/10.1108/IMEFM-11-20150137

[19] Sanlisoy, S., Aydin, U., \& Yalcinkaya, A. (2017). Effect of political risk on bank profitability. International Journal of Business Management and Economic Research (IJBMER), 8(5), 998-1007.

[20] Sanwari, S. R., \& Zakaria, R. H. (2013). The performance of Islamic banks and macroeconomic conditions. ISRA 
International Journal of Islamic

Finance, 5(2),

83-97.

https://platform.almanhal.com/GoogleSch olar/Details/?ID=2-42599\#

[21] Sanghani, D. A. (2014). The effect of liquidity on the financial performance of non-financial companies listed at the Nairobi Securities Exchange. (Unpublished master's thesis). The University of Nairobi, Nairobi, Kenya. http://hdl.handle.net/11295/74795

[22] Shahzad, A., \& Al-Swidi, A. K. (2013). Effect of macroeconomic variables on the FDI inflows: The moderating role of political stability: An evidence from Pakistan. Asian Social Science, 9(9), 270279.

http://dx.doi.org/10.5539/ass.v9n9p270

[23] Sheikh, N. A., \& Qureshi, M. A. (2017). Determinants of capital structure of Islamic and conventional commercial banks. International Journal of Islamic and Middle Eastern Finance and Management, 10(1),

24-41. https://doi.org/10.1108/IMEFM-10-20150119

[24] State Bank of Pakistan. (2020). About Islamic Banking. Retrieved from http://www.sbp.org.pk/IB/About.asp

[25] State Bank of Pakistan. (2019). Islamic Banking Bulletin. Retrieved from http://www.sbp.org.pk/ibd/bulletin/2019/J un.pdf

[26] Zainudin, R., Mahdzan, N. S. A., \& Leong, E. S. (2018). Firm-specific internal determinants of profitability performance: An exploratory study of selected life insurance firms in Asia. Journal of Asia Business

Studies. https://doi.org/10.1108/JABS-09-2016$\underline{0129}$

\section{APPENDIX}

Table A: Jarque-Bera Normality Test Results

\begin{tabular}{ll}
\hline Jarque-Bera & 194.211 \\
\hline Probability & 0 \\
\hline
\end{tabular}

Table B: Multicollinearity Test Results

\begin{tabular}{lllllll}
\hline & VIF & 1/VIF & LEV & LIQ & SIZ & PS \\
\hline LEV & 4.193 & 0.238 & 1 & & & \\
LIQ & 1.043 & 0.958 & 0.0248 & 1 & & \\
SIZ & 4.217 & 0.237 & 0.869 & -0.053 & 1 & \\
PS & 1.030 & 0.970 & 0.064 & -0.145 & 0.097 & 1 \\
\hline
\end{tabular}

Table C: Autocorrelation Test Results

\begin{tabular}{llll}
\hline F-statistic & 13.574 & Prob. F (1,59) & 0 \\
\hline Obs.*R-squared & 12.157 & Prob. Chi-Square (1) & 0 \\
\hline
\end{tabular}

Table D: Heteroscedasticity Test Results

\begin{tabular}{llll}
\hline F-statistic & 6.928 & Prob. F (4,60) & 0 \\
\hline Obs.*R-squared & 20.537 & Prob. Chi. Square (4) & 0 \\
\hline
\end{tabular}

Table E: Hausman Test Results

\begin{tabular}{llll}
\hline Test Summary & Chi-Sq. Statistic & Chi-Sq. d.f. & Prob. \\
\hline Cross-section random & 0 & 4 & 1 \\
\hline
\end{tabular}

